\title{
The Effect of Natural Resources on Civil War Reconsidered
}

\author{
Rafael Reuveny ${ }^{1} \&$ Katherine Barbieri ${ }^{2}$ \\ ${ }^{1}$ School of Public and Environmental Affairs, Indiana University, Bloomington, Indiana \\ ${ }^{2}$ Department of Political Science, University of South Carolina, Columbia, South Carolina \\ Correspondence: Rafael Reuveny, School of Public and Environmental Affairs, Indiana University, $141510^{\text {th }}$ Street, \\ Bloomington, Indiana 47405, United States.
}

Received: December 29, 2015

Accepted: March 28, 2016

Available online: March 29, 2016

doi:10.11114/ijsss.v4i5.1500

URL: http://dx.doi.org/10.11114/ijsss.v4i5.1500

\begin{abstract}
This paper reconsiders the role of natural resources in civil wars in light of the continuing debate over whether resource scarcity/abundance fuels conflict. We argue the role of resources in a civil war is due to their life-preserving and income-generating attributes, not their scarcity or abundance per se; and the effect may differ across resources and depending upon whether we examine the onset versus the presence of civil war. We highlight the need to consider comprehensive sets of life-preserving and income-generating resources in tandem, as any given resource may affect others by way of belonging to the same economy and physical environment. The empirical investigation employs a large-N statistical analysis of civil wars. The independent variables include broad sets of life-preserving resources, including key environmental conditions pertaining to hospitable climate, and income-generating resources. The results indicate that the role of resources in civil war varies by the resource. The size of effect varies depending on whether we examine civil war onset or presence, but the sign of the effect essentially does not.
\end{abstract}

Keywords: Empirical, Large N sample, Statistical Model, Multiple Resources

\section{Introduction}

"Whiskey is for drinking, water is for fighting over." This quote, often attributed to the great American writer and humorist Mark Twain, captures part of the current debate on the role of natural resources in civil wars. In one view, resource scarcity is a major driver of civil wars. A second view argues that resource abundance-not scarcity-is a major driver. The debate has generated a large body of case studies and statistical models, but the results have not revealed a clear pattern. There is still no consensus. ${ }^{\mathrm{i}}$

We reconsider this debate in hopes of contributing to both the theoretical and the empirical modeling literature. We make four key points. (1) The role of resources in a civil war is due to their life-preserving and income-generating attributes, not scarcity or abundance. (2) The direction or sign of effects of resource changes on the likelihood or risk of civil wars may differ by the resource. (3) The sizes of effect may vary depending upon whether we model onset or continuation (presence) of civil wars. (4) Empirical models need to include a broad set of life-preserving and income-generating resources, as resource changes may affect each other by way of belonging to the same ecological-socioeconomic system. Models including one or few resource measures and studies using broad resource aggregates may produce misleading results, and models for onset alone may produce partial results.

Our theory suggests that increases in life-preserving and income-generating resources may increase or decrease the risk of civil war, and the size of effect may vary for onset and presence. The nature of the effect is an empirical issue. We develop a regression model for a large $\mathrm{N}$ sample of years and countries and employ control variables widely used in the literature. The basic idea is not to create a moving target; our interventions in theory and model structure are massive enough to merit a careful approach that does not change everything at the same time. The unit of analysis is the country-year, as is common in such studies. We measure the dependent variable in two ways: civil war onset focuses on the first year of the war, and civil war presence examines all the years of a civil war that lasts more than one year.

Summarizing our main results, we find the role natural resources play in civil war varies across different types of resources. Increases in amounts of some resources increase the risk of civil war, increases in other resources decrease the risk while changes for a third group have no effect. The size of effects varies for civil war onset or presence, but with one exception, the sign of the effect is always the same. 
These results hold on average, not in each possible case on its own, as is the case for all regression models. Resources that have no significant effect in our model may have played a role in certain civil wars, or could do so in the future while resources that do play a role in our model may have been unimportant in some cases. In the rest of the paper, we review the prior literature, present our theory, describe our model, detail the findings, and discuss future research and implications for public policy.

\section{Prior Literature}

The body of literature is too large to be fully reviewed here, so we highlight representative studies and results. There are two broad types of studies, those examining the effect of resource scarcity on civil war and those looking at the effect of resource abundance.

Many scholars argue that scarcity of resources such as fertile land, water, forests, and food can lead to economic decline, reducing state ability to provide services and law and order. Grievances over access to resources and the functioning of the state may rise, increasing the risk of revolt. Natural disasters may make things worse by damaging resources and state capabilities, causing concerns over inadequate relief and/or defenses, and reducing law and order. Others argue scarcity-induced factors reduce the risk of civil war by reducing the capabilities and willingness to fight, and increasing the chances of cooperation facing a common problem and profit-motivated innovation to alleviate it. ${ }^{\text {ii }}$

Other scholars argue that forces already inclined for conflict may fight over abundant resources such as oil, minerals, farming commodities, and timber to finance arms purchase, training, and recruitment, and/or to enrich themselves. In another logic, resource-rich regions may seek to secede, which the state is likely to reject. Resource-rich countries may also experience more public grievances against the state than other countries due to the so-called resource curse. Resource booms may draw investment from other sectors, harming them, and foreign investment in the resource sector may appreciate the currency, making other exports less competitive. Rent seeking may rise in the resource sector, leading to state corruption and mismanagement. The government may pay less attention to public needs since the ongoing resource revenues reduce its dependence on taxation. These factors raise the risk of civil war, but some scholars argue that the government of resource-rich states can essentially buy followers' and public support by using resource revenues for paybacks and/or to provide public goods such as free education, healthcare, and help with housing. .ii $^{-}$

In empirical studies, many case studies find links from scarcity and disasters to civil war; others find no effect. ${ }^{\text {iv }}$ For statistical models, Esty et al. (1999) find that changes in soil degradation, deforestation, and water scarcity have no effect, and Hauge and Ellingsen (2001) find they have a risk-raising effect. De Soysa (2002) finds no effect for an index of cropland, pasture, timber, other forest goods, and subsoil assets. Urdal (2005) finds negative or no effect on population divided by a sum of cropland, pasture, woodland, forest, and arable land. Binningsbø, De Soysa, and Gleditsch (2007) find a negative effect for ecological footprint (a broad total of resource pressures). Hendrix and Glaser (2007) find no effect for degraded land and a positive effect for water. Theisen (2008) finds water has no effect and land degradation has a negative effect. Weezel (2015) finds no effect for rainfall, but the literature also reports positive and negative effects (Wischnath \& Buhaug, 2014). For natural disasters, Nel and Righarts (2008) and Eastin (2015) find a positive effect, Slettebak (2012) a negative effect, and Bergholt and Lujala. (2012) find no effect.

Case studies show links from abundant minerals, oil, timber, agrarian commodities, and diamonds to civil war. ${ }^{\mathrm{v}}$ Hyeran (2015) says $41 \%$ of rebel groups in 1985-2009 rely chiefly on resources and 27\% partly. Yet, many states with these abundant resources are internally peaceful (e.g., Australia, Brazil, Botswana, Canada, Ghana, Norway, South Africa, U.S., and Venezuela). For models, Elbadawi and Sambanis (2002), Fearon and Laitin (2003), and Fearon (2005) find no effect for primary commodity export (food and non-food agronomy, raw materials, oil, and other material); Collier, Hoeffler, and Rohner (2009) find an inverted U curve. Humphreys (2005) finds agricultural output value raises the risk. Fjelde (2015) finds the opposite. Lujala, Gleditsch, and Gilmore (2005) find diamonds have mixed effects; Ross (2006) finds a positive effect, noting there are only a few cases. For oil, Fearon and Laitin (2003) find positive effect, De Soysa and Neumayer (2007) mixed impact, Basedau and Lay (2009) negative, and Smith (2015) no effect. For minerals, Welsch (2008) finds a positive effect and Rus (2012) finds no effect.

Taking stock of the literature, the case study results are not generalizable and the statistical results are mixed. Recent reviews have offered some interpretations. Koubi, Spilker, Tobias, and Bernauer (2014) see little evidence for scarcity as a cause, and some support for abundance. Eastin (2015) sees mixed support for disasters as a cause and strong support for disasters prolonging wars. Tobias (2015) sees unsettled evidence for scarcity and much support in case studies. Murshed (2015) concludes the effect of abundant resources is not robust. We observe that the samples, designs, control variables, and estimation techniques are not significantly different. Perhaps the mixed results have to do with the inclusion of one or few resources in the model, or one broad resource aggregate. We can gain insight by reconsidering the theoretical basis for the effect of resources on the risk of civil war. 


\section{Approach and Hypotheses}

The previous section highlights disagreements about the role of resources in civil war. The scarcity camp says that a decline in scarce resources raises the risk of civil war while the abundance camp says a rise in abundant resources raises this risk. This discourse is valuable, but framing the debate in terms of scarcity versus abundance is not without limitations. We offer an alternative approach to express the debate and state implied hypotheses.

Studies typically talk about scarcity and abundance loosely. Something is scarce if there is not enough of it to satisfy wants and abundant if there is more than enough of it to go around. Studies usually expect that renewable resources are linked to civil war via scarcity, and non-renewable via abundance (Koubi et al., 2014). Yet does this imply scarcity and abundance? Why is it that non-renewable resources cannot be scarce or renewable resources cannot be abundant? What prevents rebels and state forces from using (scarce) renewable resources to fund their war? Is a non-renewable resource abundant only if someone fights over it? Moreover, how do we know if a resource is scarce or abundant in the more general context? Do we ask people if their wants are satisfied? Indeed, as one review noted recently, the definitions of scarcity and abundance are still not adequate (Mildner, Lauster \& Wodni, 2012).

In fact, scarcity and abundance link to demand and supply from economics. Demand indicates how much of a good people want to buy at a given price, given factors such as laws, quality, and substitutes. Supply indicates how much of the good firms seek to produce by price, given factors such as laws, substitutes, and other market outlets. If demand exceeds supply, there is scarcity; if supply is greater than demand, there is abundance. Economics shows that free markets tend to balance demand and supply by good, so scarcity and abundance are transient. This also applies to resources. It is difficult to decide if resources or any other goods are scarce or abundant. Further complicating the matter, demand and supply are not observable; they are estimated based on data. This complex task is particularly arduous for resources not traded in markets (e.g., rainfall, good climate, water in a river, forests). Linking resource import to scarcity and export to abundance, as some do, is problematic because in some cases the export may cause scarcity (less available at home) and the import abundance (more available). Estimating resource demand and supply by resource and country is a Herculean task; we do not know of any study that has systematically done it.

An alternative approach begins by observing that renewable resources such as fertile land, fresh water, and food crops are crucial for preserving life and have no readily available substitutes on a global basis. Resources such as precipitation and hospitable climate (e.g., the absence of weather disasters) share these attributes. We label these types of resources as life-preserving resources. Non-renewable resources such as minerals and fossil fuels, and renewables such as timber, in contrast, are not crucial for life per se, have readily available substitutes, and are market-ready in their extracted form. For example, oil and metals have substitutes, and we can essentially survive without them even if their substitutes are not readily available; it is their market value, rather than intrinsic value, that gives them importance. We refer to these resources as income-generating resources.

The two resource classes may sometimes overlap. For example, oil for pumps that defend a city lying below sea level behind a dike preserves life, and selling freshwater generates income. Ultimately, however, society cannot survive without fresh water while people living in that city can move elsewhere. The two resource groups are valued for different reasons-survival and lack of substitutes versus market-ready extraction and substitutability. Using these categories enables moving from the non-observable to observable attributes, and is useful in forming hypotheses for the effect of resource changes on the risk of civil war.

When a life-preserving resource rises, people have fewer grievances and less incentive to fight even if their share of the pie is smaller than that of others. People are more open to cooperate over resource innovation and management since the potential gains increase with resource availability. Rebels find it harder to mobilize recruits. These forces reduce the risk of civil war. We get hypothesis $\mathrm{H} 1$.

H1: An increase in a life-preserving resource reduces the risk of civil war.

Contrary to H1, when a life-preserving resource rises, people have more energy and wealth, so they are more able to support the rebels and fight for their cause. Cooperation declines since there is less need to innovate and replace the resource substitute and/or find ways to manage a scarce resource, so people are more willing to consider the rebels' cause. We get hypothesis $\mathrm{H} 2$.

$\mathrm{H} 2$ : An increase in a life-preserving resource increases the risk of civil war.

A rise in an income-generating resource raises the incentives for rebels to seize it for financing their war effort, and for the state to hold it for financing its operations. A resource-rich region has a greater incentive to secede and keep the income, and the state has a greater incentive to keep the region, by force if need be. A resource-curse evolves, weakening the state by reducing its support. These forces raise the risk of civil war. We get hypothesis $\mathrm{H} 3$.

H3: $\quad$ Rises in income-generating resources increase the risk of civil war. 
Contrary to $\mathrm{H} 3$, a rise in income-generating resource enables the state to repress a revolt before it turns into a civil war by financing better police and security forces. The state uses the income to pay its followers and to placate the public with free services. The state has more production inputs required for resource extraction than the rebels have, so it benefits relatively more due to a resource increase and can suppress revolts. We get hypothesis H4.

H4: Rises in income-generating resources reduce the risk of civil war.

The sizes of effects may differ across onset and presence since considerations may change as a war goes on. Rises in life-preserving resources become more important as a civil war continues since war damages them, which reduces the provision of basic needs. The negative (H1) or positive (H2) effect of a rise in life-preserving resources on civil war is thus larger for presence than for onset. We get hypothesis H5:

H5: $\quad$ Rises in life-preserving resources have larger absolute value effects on war presence than on onset.

As a war continues, however, casualties rise and families break up (e.g., people become stranded in different areas; people emigrate). Mental and physical energies decline and people become less responsive to a rise in a life-preserving resource in terms of joining combatants in the war, so fighting declines. We get hypothesis H6.

H6: Rises in life-preserving resources have larger absolute value effects on war onset than on presence.

A rise in income-generating resources implies more income possibilities. It entices rebels to seize resources and use the money to start a rebellion, and the state to strengthen its police and security forces. As a civil war continues, damages to the resource sector reduce its income-generation effect. We get hypothesis $\mathrm{H} 7$.

H7: Rises in income-generating resources have larger absolute value effects on war onset than on presence.

As a civil war continues, the economy declines, so the income-generating resources become more important for everyone. Combatants become more reliant on this income for their war effort activities. A rise in income-generating resources at this stage becomes relatively more important than when the war starts. We get hypothesis H8.

H8: $\quad$ Rises in income-generating resources have larger absolute values effects on war presence than on onset.

\section{Empirical Method}

All the hypotheses formulated in the previous section are logically plausible, so theory cannot decide among them. We need to conduct an empirical test. This section presents our empirical method. We seek to make general statements about the effect of resources on civil war, on average, so we use regression analysis for a large $\mathrm{N}$ sample of countries and years. Our theory suggests the effect of resource changes may vary by the resource. Variables that lump many resource types cannot capture such variation and may even generate misleading results. Including few resources is also problematic. Resources may affect each other since they are parts of the national economy and physical environment (e.g., agriculture uses oil; disasters destroy resources; water affects land productivity) and relying on one or a few resource measures may represent the effect of excluded resources. We need to include a broad set of life-preserving and income-generating resources. Our hypotheses also suggest the effect of resources may vary by onset and presence, so we need to examine models for both.

\subsection{Dependent and Independent Variables}

For the dependent variable, we include wars meeting the Fearon and Laitin (2003) criteria. (1) A government fought a non-state group that wanted to topple it, control a region, or change state policies by using violence. (2) At least 1000 people died overall during the war years with a yearly average of at least 100. (3) At least 100 people died on each side. Onset is set to one in the first year of a war and is set to zero otherwise. Presence equals one during each year of a war and equals zero otherwise.

The independent or key variables include resource measures and population. For life-preserving resources, we include measures of fresh water, arable land, cropland, weather-related disasters (a rise in this variable is akin to a decline in the resource hospitable climate), and precipitation (a proxy for farming conditions, holding weather disasters constant). One cannot easily convert these resources to income on an ongoing basis, but their use supports life. For income-generating resources, we include timber extraction, fuel extraction, mineral extraction, and agricultural goods. One can quite easily convert these resource extractions to income by selling them to domestic and/or international buyers.

WATER is the total yearly internal and external (flowing into a country) fresh water, per capita. Data in five-year intervals come from the AQUASTAT database of United Nation's Food and Agricultural Organization (FAO); we interpolate to get yearly data. Internal water is in cubic meters $\left(\mathrm{m}^{3}\right)$ per capita and external in billions of cubic meters, which we convert to cubic meters and divide by population. WEATHER DISASTERS is the yearly number of people killed by weather disasters (e.g., storms, floods, droughts), per million people. Data come from Environmental Data Explorer (EDE). PRECIPITATION is the mean yearly level in millimeters. Data in five-year intervals come from 
AQUASTAT. ARABLE LAND includes land under temporary crops (sown and reaped in an agrarian period; e.g., wheat, rice, barely), temporary meadows for mowing and pasture, market and kitchen gardens, and farmland left fallow less than five years. Data in hectares per person come from the WDI database of the World Bank. CROPLAND is the land under permanent crops (e.g., fruits, grapes, olives, nuts). Yearly data, expressed in percent of the total area, come from WDI.

TIMBER measures profits from logging trees suitable for conversion into industrial forest products (or round wood) as a percent of the gross national income, by country, per year. The FUELS variable is the total value of fuels exports (mostly but not exclusively fossil fuels such as oil), expressed as a share of merchandise exports of a country to the world. MINERALS measures profits in the mineral extraction sector (including tin, gold, lead, zinc, copper, nickel, silver, bauxite, and phosphates), as a percent of the gross national income, by country, per year. Data for these three resource extraction variables come from WDI. AGRICULTURAL OUTPUT is the value of agricultural commodities produced in a country per capita, computed at international prices, divided by this value in a base year. The data come from the FAOSTAT database of the FAO. Rises in the sizes of these empirical variables imply greater availability of income-generating resources.

POPULATION is the log of population size. The data come from WDI. A rise in population generates competing effects on the risk of civil war. It raises pressure on life-preserving resources, increasing the risk of civil war via H1, but implies greater need to alleviate the pressure and more people that can do so (e.g., Simon, 1998), reducing the risk of war via H2. Population rise makes it harder to govern and raises the pool of potential fighters and grievances, but it also complicates the coordination and mobilization of people to revolt. The effect is thus unclear.

\subsection{Control Variables}

We include typical control variables. We discuss their expected effects quite quickly; unless we note otherwise they are unclear. GDPpc denotes the gross domestic product (GDP) per capita in real terms from Fearon and Laitin (2003). A higher value may reduce war-risk, making people more content and states more able to subdue uprisings and solve problems; but richer rebels can finance more arms and recruits, raising the risk. TRADE, the sum of import and export values of a country divided by GDP, comes from WDI. A rise in trade may pacify by fulfilling needs, promoting growth, enabling states to arm, and stirring dispute resolution as war is bad for business; but it may reduce resources for home use, create job losses, damage the environment, and finance the rebels, increasing the risk.

ETHNIC / RELIGIOUS FRACTIONALIZATIONS are odds of two randomly drawn people belonging to different ethnic / religious groups. More fractionalization may raise animosity, but reduces group power. DEMOCRACY ranges from 10 (full democracy) to -10 (full autocracy). It comes from the Polity IV Project. More democracy enables expression of grievances and raises state openness, but also opposition formation. POLITICAL INSTABILITY is one if DEMOCRACY changes three points or more in any of the three prior years, and zero otherwise. A rise in instability raises the risk of war since it signals disorder and weakness at the center. The effect may be weaker on presence than onset since instability may become the norm as a war goes on.

NONCONTIGUOUS TERRITORY is one if the land of another country or at least 100 kilometers of water separate areas with at least 10,000 people from the area containing the capital city, and is zero otherwise. MOUNTAINOUS is the estimated ratio of mountainous area to the total area, logged. The data come from Fearon and Laitin. Larger values raise the risk of civil war as they provide hideouts for rebels and make it harder for the state to reach them. The effects may be larger on onset than presence as states may finally move forces to such areas. WAR COUNT counts years of war. A higher count may promote presence by entrenching animosity, but may pacify by raising weariness. PEACE YEARS is a count of the years with peace since the last war ended. A higher value may reduce the risk of civil war, as people get used to peace, but may raise it, as they may forget the horrors of war.

\subsection{Econometric Issues}

Civil war may not occur even when all the factors thought to play a role in its onset are present and may occur even when those factors are absent. This reflects the inability to model and/or to know about all the factors that play a role. All civil war models for a large $\mathrm{N}$ sample are inevitably partial since the wars themselves differ in some respects. We thus model it as a probabilistic event using the Logit regression. We use one-tailed significance tests as our hypotheses predict certain signs. For the size of each effect, we use the following procedure. (1) We compute the predicted probability of war while setting a continuous variable to one standard deviation (S.D.) above its mean, holding the other continuous variables at their means and the binary variables at zero (politically stable and contiguous countries). (2) We compute the probability holding all the continuous variables at their means and binary variables at zero. (3) We compute and report the percent change of the first probability relative to the second. For the size of a binary effect, we use the same procedure while changing the associated variable from zero to one (Tomz, Wittenberg, \& King, 2003). 
Civil war may affect some of the factors that cause it (e.g., civil war can reduce GDP per capita). To alleviate this issue, we lag all the variables, as usual, except when civil war cannot affect them (namely, for water, precipitation, disasters, and mountainous and contiguous areas). Next, the model may face serial correlation from the prevalence of peace in the data, and heteroscedasticity since country data come in different sizes. To alleviate the risk of serial correlation, we use PEACE YEARS and three auxiliary (cubic splines) terms (Beck, Katz, \& Tucker, 1998), and to alleviate the risk of heteroscedasticity we define our variables as logs or ratios. We alleviate any remaining serial correlation and heteroscedasticity by estimating robust standard errors clustered by country for the coefficient estimate. Last, we inspect the model's correlation matrix, variance inflation factors (VIF), and average VIF, to assess if multicollinearity is a concern; should it be a problem, we will take apt actions.

\section{Results}

Table 1 presents the estimation results. Appendix 1 lists the states in the sample, summary statistics, and correlation table. ${ }^{\mathrm{vi}}$ The pseudo $\mathrm{R}^{2}$ is 0.84 for presence, which is high, and 0.21 for onset, which is typical. The largest correlation between any two variables (-0.63) occurs for TRADE and GDPpc, which are correlated by construction. The other correlations are smaller than 0.38 . The largest individual VIF score is 2.29 for onset and 2.59 for presence. The average VIF score is 1.5 for onset and 1.72 for presence. Multicollinearity is not a concern.

Table 1. Estimation Results

\begin{tabular}{|c|c|c|c|c|}
\hline & \multicolumn{2}{|c|}{ War Presence } & \multicolumn{2}{|c|}{ War Onset } \\
\hline & Coefficient & St. Error & Coefficient & St. Error \\
\hline Water & 0.000 & $(0.000)$ & 0.000 & $(0.000)$ \\
\hline Precipitation & 0.0001 & $(0.0002)$ & 0.000 & $(0.001)$ \\
\hline Arable Land & $-1.568 * *$ & $(0.750)$ & $1.259 * *$ & $(0.762)$ \\
\hline Weather Disasters & $0.002 * * *$ & $(0.001)$ & $0.001 * *$ & $(0.005)$ \\
\hline Cropland & $0.088 * * *$ & $(0.0054)$ & 0.124 & $(0.111)$ \\
\hline Timber & $-0.096^{*}$ & $(0.070)$ & $-0.199 *$ & $(0.143)$ \\
\hline Agricultural Output & $0.021 * * *$ & $(0.009)$ & $0.034 * * *$ & $(0.012)$ \\
\hline Minerals & $0.175 * * *$ & $(0.055)$ & $0.128 * *$ & $(0.063)$ \\
\hline Fuels & $0.012 * *$ & $(0.007)$ & $0.023 * * *$ & $(0.008)$ \\
\hline Population & $0.450 * * *$ & $(0.197)$ & $0.541 * * *$ & $(0.217)$ \\
\hline GDPpc & $-0.120 *$ & $(0.083)$ & $-0.522 * * *$ & $(0.170)$ \\
\hline Mountainous & 0.108 & $(0.110)$ & $0.539 * * *$ & $(0.198)$ \\
\hline Noncontiguous Territory & 0.352 & $(0.577)$ & 0.577 & $(0.909)$ \\
\hline Political Instability & -0.313 & $(0.611)$ & $0.727 *$ & $(0.535)$ \\
\hline Trade & $-0.020 * *$ & $(0.010)$ & -0.010 & $(0.012)$ \\
\hline Ethnic Fractionalization & $0.788^{*}$ & $(0.563)$ & -0.237 & $(0.833)$ \\
\hline Religious Fractionalization & -0.048 & $(0.906)$ & 0.970 & $(1.315)$ \\
\hline Democracy & 0.0021 & $(0.051)$ & 0.036 & $(0.037)$ \\
\hline War Count & 0.023 & $(0.028)$ & NA & NA \\
\hline Peace Years & $-3.019 * * *$ & $(0.561)$ & 0.194 & $(0.216)$ \\
\hline Constant & -3.233 & $(2.724)$ & $-15.147 * * *$ & $(3.418)$ \\
\hline $\mathrm{N}$ & 1994 & & 1944 & \\
\hline Pseudo R2 & 0.84 & & 0.21 & \\
\hline
\end{tabular}

Description: St. Error means standard error. Robust S.E. clustered by country in parentheses. $* * *$ means significant at $1 \%$, $* * 5 \%$, and $* 10 \%$. NA means not applicable. Three cubic spline variables are included but not reported.

For the control variables, the POPULATION estimates are positive and significant for onset and presence. A rise in population raises the risk of civil war. This may indicate links from greater pressure on resources to war and/or a greater difficulty to govern, larger fighter pools, and more hideouts and supply sources for rebels. Higher GDPpc reduces the risks of onset and presence. More TRADE does not affect onset but reduces the risk of presence. An increase in the 
value of MOUNTAINOUS raises the risk of onset and does not affect the risk of presence, supporting the expectation of a stronger effect for onset. NONCONTIGUOUS TERRITORY has no effect, perhaps due to its small variation.

POLITICAL INSTABILITY raises the risk of onset and does not affect the risk of presence, supporting the expectation of a weaker effect on presence. DEMOCRACY has no effect. An increase in ETHNIC FRACTIONALIZATION does not affect the risk of civil war onset but raises the risk of presence. RELIGIOUS FRACTIONALIZATION and WAR COUNT have no effect. Changes in PEACE YEARS do not affect the risk of onset but lower the risk of presence. These results generally resemble those reported by other studies. Since the diagnostics reported above are also reasonable, we can say that our modeling platform is sound, so let us move to the resource estimates.

For the life-preserving resources, the estimates for WATER and PRECIPITATION are insignificant; this may be due the low variability of these variables by country in our dataset. The onset estimate for ARABLE LAND is significant and positive. A rise in arable land raises the risk of war onset, supporting $\mathrm{H} 2$ (more life-preserving resource $\rightarrow$ higher risk). The reading is that people now have less of a need to cooperate over resource management and more energy and wealth and so are more willing and able to join the fighting. An alternative reading observes that a country has a finite stock of fertile land suitable for temporary crops. When ARABLE LAND rises, more of the fertile land is in use and less is available for others. The losers seek a larger share of the pie and so are more likely to fight to change the status quo, raising the risk of civil war. The presence estimate for ARABLE LAND is negative and significant. A rise in arable land reduces the risk of civil war presence, supporting H1 (more life-preserving resource $\rightarrow$ less risk). Ongoing civil war damages arable land and its temporary crops (e.g., wheat), as well as the storage warehouses, roads, and factories required to use them. At this stage, a rise in arable land eases pressures on a key resource for food and reduces grievances, reducing the risk of continued civil war.

The estimates for WEATHER DISASTERS are positive and significant for both measures. A rise in weather disasters raises the risks of both civil war onset and presence. Viewing this rise as a fall in the life-preserving resource hospitable climate, these results support H1. The damages and shortages associated with weather disasters raise public gripes, making it easier for rebels to find recruits for their cause, and the associated damages to law and order and to transportation and communication networks make it harder for the state to subdue the rebels.

The onset estimate for CROPLAND indicates that a rise in cropland raises the risk of war onset at the 0.13 level. The estimate for presence is significant and positive. A rise in cropland raises the risk of civil war presence. Both estimates support $\mathrm{H} 2$ (more life-preserving resource $\rightarrow$ higher risk) though we have relatively less confidence in the onset result. With more cropland, permanent crops rise, all else the same. People are stronger, enabling both state forces and rebels to find more recruits. Rebels have more incentive to seize cropland and sell its crops to finance their war effort. An alternative reading observes that a country has a finite stock of fertile land suitable for growing permanent crops (e.g., fruits, nuts). When CROPLAND rises, less is available for others. As with ARABLE LAND, those left out are invested in changing the system, raising the risk of civil war. Unlike for ARABLE LAND, the CROPLAND effect is also positive for presence, as it is relatively easier to transport permanent crops to the marketplace and convert them to income.

For the income-generating resources, the estimate for TIMBER is negative and significant for onset and presence. A rise in timber extraction reduces the risk of civil war. This supports $\mathrm{H} 4$ (more income-generating resources $\rightarrow$ lower risk). Timber extraction requires special machinery, heavy-load transport, and large storage. The state has more of these resources than rebels do, so it gains relatively more when TIMBER rises. It can thus buy more arms and win support by paying followers and the public, subduing uprisings before they become civil wars.

The estimates for AGRICULTURAL OUTPUT, MINERALS, and FUELS are positive and significant for civil war onset and presence. Increases in the values of these variables, taken one at a time, increase the risk of civil war, supporting H3 (more income-generating resources $\rightarrow$ higher risk). The reading is that increases in these resources intensify the adverse effects of the resource curse and create more opportunities for rebels to generate income for financing their war effort.

Table 2 presents the size of effects; empty cells indicate no effect (insignificant coefficient estimate). A rise of one S.D. in ARABLE LAND above its mean, holding other levels at their mean and binary variables at zero, reduces the risk of civil war presence by $39 \%$ and raises the risk of onset by $49 \%$. The absolute value effect is larger for onset, as in hypothesis H6. A rise of one S.D. in NATURAL DISASTERS above its mean, holding the other variables as before, raises the risk of civil war presence by $62 \%$ and the risk of civil war onset by $29 \%$. The absolute value the effect is larger for presence, supporting H5. A rise of one S.D. in CROPLAND raises the risk of civil war presence by $36 \%$ and civil war onset by $53.4 \%$. The probability that we read the onset effect correctly is 0.87 . To compare the effects, we compute 53.4 x $0.87=46.46 \%$; the absolute value effect for cropland is thus larger for onset, in line with H5.

A rise of one S.D. in TIMBER reduces the risk of civil war presence by $15 \%$ and onset by $19 \%$. The effect is larger for 
onset, in line with hypothesis H7. A rise of one S.D. in AGRICULTURAL OUTPUT raises the risk of civil war presence by $98 \%$ and onset by $236 \%$. The effect is larger for onset, in line with H7. A rise of one S.D. in FUELS raises the risk of civil war presence by $50 \%$ and the risk of civil war onset by $105 \%$, in line with H7. A rise of one S.D. in MINERALS raises the risk of civil war presence by $169 \%$ and the risk of civil war onset by $80 \%$, supporting $\mathrm{H} 8$. The support of $\mathrm{H} 8$, rather than $\mathrm{H} 7$, may reflect the relative ease of extracting, transporting, storing, and selling some minerals (e.g., gold, gemstones, silver, and phosphates) compared to our other three income-generating resources. This relative ease may better enable continued use of minerals in financing war efforts as the war continues and damages to the resource extraction sectors increase.

Table 2. Sizes of Significant Effects

\begin{tabular}{llr}
\hline & War Presence \% & War Onset \% \\
\hline Arable Land & -39.38 & 48.82 \\
Weather Disasters & 62.21 & 29.31 \\
Cropland & 36.01 & $53.43^{\dagger}$ \\
Timber & -14.62 & -18.82 \\
Agricultural Output & 98.20 & 236.17 \\
Minerals & 169.38 & 80.27 \\
Fuels & 50.35 & 105.57 \\
Population & 73.19 & 111.56 \\
GDPpc & -30.83 & -74.07 \\
Mountainous & & 90.86 \\
Political Instability & & 95.23 \\
Ethnic & & \\
Fractionalization & 26.12 & \\
Trade & -41.81 & \\
Peace Years & -100.00 & \\
\hline
\end{tabular}

Description: ${ }^{\dagger}$ means significant at 0.13 .

Turning to the control variables, a rise of one S.D. in POPULATION raises the risk of civil war presence $73 \%$ and onset by $112 \%$. A similar rise in GDPpc reduces the risk of onset by $74 \%$ and presence by $31 \%$. A rise of one S.D. in the value of MOUNTAINOUS raises the risk of onset by $91 \%$. The occurrence of POLITICAL INSTABILITY raises the risk of onset by 95\%. A similar rise in ETHNIC FRACTIONALIZATION raises the risk of civil war presence by $26 \%$. Rises of one S.D. in TRADE reduces the risk of onset by 42\%, and in PEACE YEARS by $100 \%$. Thus, states with greater population, mountainous area, political instability, and ethnic fractionalization face a larger a risk of civil war than other states. States with larger values of GDP per capita and trade and those with more years of peace face lower risks of civil war.

\section{Discussion}

Table 3 summarizes the estimation results. The estimated signs of effects for onset are similar to those for presence, except for arable land. Increases in disasters, cropland, agricultural output, fuels, and minerals each increase the risk of civil war. An increase in timber reduces the risk. An increase in arable land increases the risk for civil war onset and reduces the risk for presence. Water and precipitation play no role, probably reflecting, as noted, their low variation in the sample, by country. Countries with more weather disasters, cropland, agricultural output, fuel export, and mineral income, and less timber income are at higher risk of civil war onset and presence. The significant resource effects in the model are larger than, or are on par with, the non-resource effects; the effects of agricultural output and fuels on onset and minerals on presence are the largest among all the model's variables. The disaster and mineral effects are stronger on presence than on onset. The cropland, agricultural output, fuels, arable land, and timber effects are stronger on onset than on presence. Sorting the resource effects on onset by size gives the ranking agricultural output, fuels, minerals, arable land, weather disasters, and timber. Sorting the effects on presence gives the ranking minerals, agricultural output, weather disasters, fuels, arable land, cropland, and timber. 
Table 3. Summary of Significant Results for Increases in Resources

\begin{tabular}{|c|c|c|c|}
\hline Resource & Effect on & Effect on & Larger \\
\hline Measure & Onset Risk & Presence Risk & Effect on \\
\hline Weather Disasters & Increase & Increase & Presence \\
\hline Cropland & Increase & Increase & Onset $^{\dagger}$ \\
\hline Arable Land & Increase & Decrease & Onset \\
\hline Water & & & NA \\
\hline Precipitation & & & NA \\
\hline Agricultural Output & Increase & Increase & Onset \\
\hline Fuels & Increase & Increase & Onset \\
\hline Minerals & Increase & Increase & Presence \\
\hline Timber & Decrease & Decrease & Onset \\
\hline
\end{tabular}

Description: ${ }^{\dagger}$ means significant at the $13 \%$ level, empty cell means no effect, and NA means not applicable.

These results are important, but one paper naturally can only do so much. Future research may examine measures of property rights and rent seeking, include more resources, enlarge the sample, and improve the precipitation and water measures. Other extensions may incorporate measures of state and rebel abilities to seize and sell resources and international intervention, or examine civil war escalation, duration, and termination. These extensions may be complicated, but are worth exploring using our framework to include many resource measures in one model.

Taking a broader view, in recent decades, nearly all civil wars occurred in less developed countries (LDCs). LDCs are poorer than developed countries (DCs), more prone to political instability, more fractionalized ethnically (due to their colonial past), more dependent on resources for livelihood, have higher population growth, face more weather disasters due to their location, suffer more damage per disaster (due to weaker structures and defenses), and are less able to rebuild (since they are poorer). These features put them at a higher risk of civil war than DCs.

Policies that reduce these factors reduce the risk, but the implications for timber are complex. A rise in timber reduces the risk of civil war, but extraction beyond the forest's maximum growth rate reduces its stock and is not sustainable. It will likely accelerate the rate of global warming and increase weather disasters, as most of the world's forests are in LDCs, and reduce land fertility and GDPpc, as LDCs depend on agriculture. These factors raise the risk of civil war. States can lower the risk by reducing dependence on minerals, fuel export, and agriculture. They should not avoid exploiting their resources; rather, they should invest the profits in developing other economic sectors and improving provision and quality of law and order, infrastructures, education, property rights, and other institutions to avoid the resource curse.

Finally, what are the implications of our results for the coming decades, assuming they will hold? The U.S. government's National Intelligence Council (NIC, 2012) projects declining civil war risk to 2030 in states with a median age above 25, as in Latin America, and continuing high risk in most of Sub-Saharan Africa and parts of the Middle East, South Asia, and Asian-Pacific. We cannot comment on the regional aspect of this projection, but we can use our model to say something about the average tendency.

We first need to project average resource and population levels to 2030. This large task falls outside the scope of this paper, so we rely on the NIC's expectations. The NIC expects declining availability of fuels, water, and minerals to 2030, against a backdrop of rising population, rising weather disasters, and falling rainfall (in most world regions). Agricultural output, the NIC expects, will rise to meet a greater demand for food due to population growth, and deforestation will rise to support growing agricultural land requirements, suggesting timber will decline (as forest stock will fall) and arable land and cropland will increase. ${ }^{\text {vii }}$

For these expectations, our results for weather disasters, agricultural output, cropland, arable land, timber, and population indicate a rising risk for civil war. Our model does not predict that changes in precipitation and water will affect civil war risk, but we believe this point bears examination with more nuanced data. The expected declines in fuels and minerals suggest declining civil war risk, but would reduce GDP per capita and trade for countries that rely on these resources for income. Should their GDP per capita and trade fall, they would face a higher risk of civil war. Generating an overall projection is not easy as there are competing effects, but rising chances for civil war still seem likely, just as the NIC expects, provided, again, that our estimates will hold, and the NIC's projections will arise. These conditions may not hold true, but it is better to prepare for a worse scenario that will not emerge than simply hope that it will not 
come to pass.

\section{References}

AQUASTAT, Food and Agriculture Organization (FAO) of the United Nations, Rome, Italy. http://www.fao.org/nr/water/aquastat/data/query/index.html?lang=en

Basedau, M., \& Lay, J. (2009) Resource Curse or Rentier Peace? The Ambiguous Effects of Oil Wealth and Oil Dependence. Journal of Peace Research, 46(6), 757-776. http://dx.doi.org/10.1177/0022343309340500

Beck, N., Katz, J. N., \& Tucker, R. (1998). Taking Time Seriously in Binary Time-Series--Cross-Section Analysis. American Journal of Political Science, 42(4), 1260-1288. http://dx.doi.org/10.2307/2991844

Bergholt, D., \& Lujala, P. (2012). Climate-related natural disasters, economic growth, and armed civil conflict. Journal of Peace Research, 49(1), 147-162. http://dx.doi.org/10.1177/0022343311426167

Binningsbø, H. M., De Soysa, I., \& Gleditsch, N. P. (2007), Green giant or straw man? Environmental pressure and civil conflict, 1961-99. Population and Environment, 28(6), 337-353. http://dx.doi.org/10.1007/s11111-007-0053-6

Blondel, A. (2004). The Logs of War. New York, NY: Global Policy Forum. https://www.globalpolicy.org/component/content/article/198/40325.html

Collier, P., Hoeffler, A., \& Rohner, D. (2009). Beyond greed and grievance: feasibility and civil war. Oxford Economic Papers, 61(1), 1-27, http://dx.doi.org/10.1093/oep/gpn029

De Soysa, I. (2002). Ecoviolence: Shrinking Pie, or Honey Pot? Global Environmental Politics, 2(4), 1-34. http://dx.doi.org/10.1162/152638002320980605

De Soysa, I., \& Neumayer, E. (2007). Resource Wealth and the Risk of Civil War Onset: Results from a New Dataset of Natural Resource Rents, 1970-1999. Conflict Management and Peace Science, 24(3), 201-218. http://dx.doi.org/10.1080/07388940701468468

Eastin, J. (2015). Fuel to the Fire: Natural Disasters and the Duration of Civil Conflict. International Interactions. Online. http://dx.doi.org/10.1080/03050629.2016.1115402.

Elbadawi, I., \& Sambanis, N. (2002). How Much War Will We See? Explaining the Prevalence of Civil War. Journal of Conflict Resolution, 46(3), 307-334. http://dx.doi.org/10.1177/0022002702046003001

Environmental Data Explorer (EDE), United Nations Environmental Programme, Nairobi, Kenya. http://geodata.grid.unep.ch/extras/datasetlist.php

Esty, D. C., Goldstone, J. A., Gurr, R. T., Harff, B., Levy, M., Dabelko, G. D., Surko, P. T., \& Unger, A. N. (1999). State Failure Task Force Report: Phase II Findings. Environmental Change \& Security Project, 5(summer), 49-72.

EUISS (2012). European Strategy for Policy Analysis, Global trends 2030 - Citizens in an interconnected and polycentric world. Institute for Security Studies of the European Union. Paris, France.

FAOSTAT, Food and Agriculture Organization (FAO) of the United Nations, Rome, Italy. http://faostat3.fao.org/download/Q/QI/E

Fearon, J. D. (2005). Primary Commodity Exports and Civil War. Journal of Conflict Resolution, 49(4), 483-507. http://dx.doi.org/10.1177/0022002705277544

Fearon, J. D., \& Laitin D. D. (2003). Ethnicity, Insurgency, and Civil War. American Political Science Review, 97(1), 75-90. http://dx.doi.org/10.1017/S0003055403000534

Fjelde, H. (2015). Farming or Fighting? Agricultural Price Shocks and Civil War in Africa. World Development, 67(3), 525-534. http://dx.doi.org/10.1016/j.worlddev.2014.10.032

Hauge, W. \& Ellingsen, T. (2001). Causal Pathways to Conflict. In Diehl, P. F. \& Gleditsch, N. P. (Eds.), Environmental Conflict, 13-35. Boulder, CO: Westview.

Hendrix, C. S., \& Glaser, S. M. (2007). Trends and triggers: Climate, climate change and civil conflict in Sub-Saharan Africa. Political Geography, 26(6), 695-715. http://dx.doi.org/10.1016/j.polgeo.2007.06.006

Homer-Dixon, T. F. (2001). Environment, Scarcity, and Violence. Princeton, NJ: Princeton University Press.

Humphreys, M. (2005). Natural Resources, Conflict, and Conflict Resolution: Uncovering the Mechanisms. Journal of Conflict Resolution, 49(4), 508-537. http://dx.doi.org/10.1177/0022002705277545

Hyeran, J. (2015). Compliant Rebels Rebel Groups and International Law in World Politics. Cambridge, UK: Cambridge University Press.

Kahl, H. C. (2005). Plight or Plunder? Natural Resources and Civil War. In P. Dombrowski (Ed.) Guns and Butter: The Political Economy of International Security, Boulder, CO: Lynne Rienner, 77-98.

Kahl, H. C. (2008). States, Scarcity, and Civil Strife in the Developing World. Princeton, NJ: Princeton University Press.

Klare, M. (2002). Resource Wars: The New Landscape of Global Conflict. New York, NY: Holt.

Koubi, V., Spilker, G., Tobias, B., \& Bernauer, T. (2014). Do natural resources matter for interstate and intrastate armed conflict? Journal of Peace Research, 51(2), 227-243. http://dx.doi.org/10.1177/0022343313493455

Le Billon, P. (2012). Wars of Plunder: Conflicts, Profits and the Politics of Resources. New York, NY: Columbia University Press. 
Lujala A, Gleditsch, N. P., \& Gilmore E. (2005). Diamond Curse? Civil War and a Lootable Resource. Journal of Conflict Resolution, 49(4), 538-562, http://dx.doi.org/10.1177/0022002705277548

Matthew, R. A., \& Upreti, B. R. (2010). Environmental Change and Human Security in Nepal. In R. A. Matthew, J. Barnett, B. McDonald, \& L. K. O’Brien (Eds.), Global Environmental Change and Human Security Cambridge, MA: The MIT Press, 137-194.

Mildner, S. A. Lauster, G., Wondi, W. (2012). Scarcity and Abundance Revisited: A Literature Review on Natural Resources and Conflict. International Journal of Conflict and Violence, 5(1), 155-172. www.ijcv.org/index.php/ijcv/article/view/113

Murshed, S. M. (2015). On the nature of disagreements regarding the causes of civil war. In P. Jackson (Ed.), Handbook of International Security and Development. Cheltenham, UK: Edward Elgar Publishing, 19-31.

Nel, P., \& Righarts, M. (2008). Natural Disasters and the Risk of Violent Civil Conflict. International Studies Quarterly. 52(1), 159-185. http://dx.doi.org/10.1111/j.1468-2478.2007.00495.x

NIC (2012). Global Trends 2030: Alternative Worlds. National Intelligence Council, Office of the Director of National Intelligence, United States. Oxford Economic Papers, 61(1), 1-27, http://dx.doi.org/10.1093/oep/gpn029

Polity IV Project. Political Regime Characteristics and Transitions, 1800-2013. Vienna, VA: Center for Systemic Peace. http://www.systemicpeace.org/.

Reuveny, R. (2008). Ecomigration and Violent Conflict: Case Studies and Public Policy Implications. Human Ecology, 36(1), 1-13. http://dx.doi.org/10.1007/s10745-007-9142-5

Ross, M. (2006). A Closer Look at Oil, Diamonds, and Civil War. Annual Review of Political Science, 9, 265-300. http://dx.doi.org/10.1146/annurev.polisci.9.081304.161338

Rus, H. A. (2012). Environmental Depletion, Governance, and Conflict. Southern Economic Journal, 78(4), 1305-1332. http://dx.doi.org/10.4284/0038-4038-78.4.1305

Salehyan, I., \& Hendrix, C. S. (2014). Climate shocks and political violence. Global Environmental Change, 28(5), 239-250. http://dx.doi.org/10.1016/j.gloenvcha.2014.07.007

Simon, J. L. (1998). The Ultimate Resource 2. Princeton, NJ: Princeton University Press.

Slettebak, R. T. (2012). Don't blame the weather! Climate-related natural disasters and civil conflict. Journal of Peace Research, 49(1), 163-176. http://dx.doi.org/10.1177/0022343311425693

Smith, B. (2015). Resource wealth as rent leverage: Rethinking the oil-stability nexus. Conflict Management and Peace Science. Online. http://dx.doi.org/10.1177/0738894215609000

STP (2014). Global Strategic Trends - Out to 2045. Strategic Trends Programme. Fifth Edition. Ministry of Defence, United Kingdom.

Theisen, O. M. (2008) Blood and Soil? Resource Scarcity and Internal Armed Conflict Revisited. Journal of Peace Research, 45(6), 801-818. http://dx.doi.org/10.1177/0022343308096157

Tobias, I. (2015). Why do conflicts over scarce renewable resources turn violent? A qualitative comparative analysis. Global Environmental Change, 33(4), 61-70. http://dx.doi.org/10.1016/j.gloenvcha.2015.04.008

Tomz, M., Wittenberg, J., \& King G. (2003). CLARIFY: Software for Interpreting and Presenting Statistical Results. Version 2.1. Journal of Statistical Software. 8(i01). http://econpapers.repec.org/article/jssjstsof/08_3ai01.htm

Urdal, H. (2005). People vs. Malthus: Population Pressures, Environmental Degradation, and Armed Conflict Revisited. Journal of Peace Research, 42(4), 417-434. http://dx.doi.org/10.1177/0022343305054089

WDI, World Development Indicators (WDI). World Bank. Washington D.C. http://data.worldbank.org/data-catalog/world-development-indicators

Weezel, V. S. (2015) Economic shocks \& civil conflict onset in Sub-Saharan Africa, 1981-2010. Defense and Peace Economics, 26(2), 153-177. http://dx.doi.org/10.1080/10242694.2014.887489

Welsch, H. (2008). Resource abundance and internal armed conflict: Types of natural resources and the incidence of 'new wars'. Ecological Economics, 67(3), 503-513. http://dx.doi.org/10.1016/j.ecolecon.2008.01.004

Wischnath, G. \& Buhaug, H. (2014). On climate variability and civil war in Asia. Climatic Change, 122(4), 709-721. http://dx.doi.org/10.1007/s10584-013-1004-0 


\section{Appendix}

Table 1.Countries in the Sample

\begin{tabular}{lll}
\hline & \multicolumn{1}{c}{ Countries } & \\
\hline Algeria & Angola & Argentina \\
Armenia & Australia & Austria \\
Azerbaijan & Bahrain & Bangladesh \\
Belarus & Benin & Bhutan \\
Bolivia & Brazil & Bulgaria \\
Burkina Faso & Burundi & Cameroon \\
Canada & The Central African Republic & Chad \\
Chile & China & Colombia \\
Congo & Costa Rica & Cyprus \\
Denmark & Dominican Republic & Ecuador \\
Egypt & El Salvador & Estonia \\
Estonia & Ethiopia & Fiji \\
Finland & France & Gabon \\
Gambia & Georgia & Ghana \\
Greece & Guatemala & Guinea \\
Guinea-Bissau & Guyana & Haiti \\
Honduras & Hungary & India \\
Indonesia & Iran & Ireland \\
Israel & Italy & Ivory Coast \\
Jamaica & Japan & Jordan \\
Kazakhstan & Kenya & Kuwait \\
Kyrgyzstan & Latvia & Libya \\
Lithuania & Madagascar & Malawi \\
Malaysia & Mali & Mauritania \\
Mauritius & Mexico & Moldova \\
Mongolia & Morocco & Mozambique \\
Nepal & Netherlands & New Zealand \\
Nicaragua & Thiger & Nigeria \\
Oman & Pakistan & Panama \\
Papua New Guinea & Paraguay & Peru \\
Philippines & Poland & Portugal \\
Romania & Russia & Rwanda \\
Saudi Arabia & Senegal & Sierra Leone \\
South Africa & South Korea & Spain \\
Sri Lanka & Sudan & Sweden \\
Switzerland & Syria & Tanzania \\
Thailand & Togo & Trinidad Tobago \\
Tunisia & Turkey & Turkmenistan \\
Uganda & Ukraine & United Arab Emirates \\
United Kingdom & Uruguay \\
Venezuela & & \\
\hline & Zimbabwe \\
\hline
\end{tabular}


Table A2. Summary Statistics

\begin{tabular}{lllllr}
\hline Variable & Units & Mean & St. Deviation & Minimum & Maximum \\
\hline Water & m /year & 28462.88 & 59545.30 & 8 & 748217.00 \\
Precipitation & mm/year & 1113.25 & 747.33 & 51.2 & 3141.70 \\
Arable Land & ha/person & 344.78 & 3454.92 & 0.00025 & 51200.00 \\
Weather Disasters & killed/million & 13.22 & 233.13 & 0 & 7630.01 \\
Cropland & \% of area & 2.66 & 3.66 & 0.00064 & 17.61 \\
Timber & \% of GNI & 0.50 & 1.49 & 0 & 18.52 \\
Agricultural Output & Index/person & 106.13 & 79.79 & 9.5 & 1457.70 \\
Minerals & \% of GNI & 1.49 & 5.25 & 0 & 82.59 \\
Fuels & \% of Mer. Exp. & 16.13 & 35.24 & 0 & 99.99 \\
Population & log (persons) & 9.05 & 1.47 & 5.40 & 14.03 \\
GDPpc & constant 1985 I\$ & 3.95 & 4.85 & 0.13 & 66.74 \\
Mountainous & log (\% of area) & 2.11 & 1.42 & 0 & 4.56 \\
Noncontiguous Territory & binary & 0.16 & 0.37 & 0 & 1 \\
Political Instability & binary & 0.14 & 0.35 & 0 & 1 \\
Trade & \% of GDP & 60.43 & 34.11 & 1.53 & 282.40 \\
Ethnic Fractionalization & probability & 0.40 & 0.29 & 0.001 & 0.93 \\
Religious Fractionalization & probability & 0.37 & 0.22 & 0 & 0.78 \\
Democracy & index & -0.59 & 7.53 & -10 & 10 \\
War Count & years & 1.83 & 6.12 & 0 & 51 \\
Peace Years & years & 13.59 & 11.84 & 0 & 39 \\
\hline
\end{tabular}

Description: GNI means Gross National Income, Mer. Exp. merchandise export, and I\$ international dollars (adjusted for purchasing power parity).

Table A3. Correlation Table

\begin{tabular}{|c|c|c|c|c|c|c|c|c|c|c|c|c|c|c|c|c|c|c|c|}
\hline & No. & 1 & 2 & 3 & 4 & 5 & 6 & 7 & 8 & 9 & 10 & 11 & 12 & 13 & 14 & 15 & 16 & 17 & 18 \\
\hline Water & 1 & 1.00 & & & & & & & & & & & & & & & & & \\
\hline Arable Land & 2 & 0.11 & 1.00 & & & & & & & & & & & & & & & & \\
\hline Weather Disasters & 3 & 0.00 & -0.02 & 1.00 & & & & & & & & & & & & & & & \\
\hline Cropland & 4 & -0.20 & -0.25 & 0.01 & 1.00 & & & & & & & & & & & & & & \\
\hline Precipitation & 5 & 0.33 & -0.27 & 0.08 & 0.30 & 1.00 & & & & & & & & & & & & & \\
\hline Population & 6 & -0.24 & 0.05 & 0.01 & -0.03 & -0.07 & 1.00 & & & & & & & & & & & & \\
\hline Agricultural Output & 7 & 0.04 & -0.10 & 0.01 & 0.06 & 0.08 & -0.24 & 1.00 & & & & & & & & & & & \\
\hline Timber & 8 & -0.09 & -0.08 & 0.02 & 0.14 & 0.13 & 0.06 & -0.01 & 1.00 & & & & & & & & & & \\
\hline Minerals & 9 & 0.35 & 0.06 & -0.01 & -0.07 & 0.14 & -0.13 & -0.03 & -0.04 & 1.00 & & & & & & & & & \\
\hline Fuels & 10 & 0.13 & -0.05 & 0.00 & -0.10 & -0.14 & -0.06 & -0.04 & -0.12 & -0.12 & 1.00 & & & & & & & & \\
\hline Trade & 11 & 0.12 & -0.19 & -0.02 & 0.15 & 0.00 & -0.63 & 0.23 & -0.07 & 0.14 & 0.15 & 1.00 & & & & & & & \\
\hline GDPpc & 12 & -0.06 & 0.24 & -0.04 & -0.14 & -0.24 & 0.00 & -0.01 & -0.27 & -0.18 & 0.01 & 0.07 & 1.00 & & & & & & \\
\hline Mountainous & 13 & 0.02 & -0.05 & 0.05 & 0.07 & 0.14 & 0.34 & -0.06 & 0.04 & 0.06 & -0.07 & -0.35 & -0.08 & 1.00 & & & & & \\
\hline Noncontiguous & 14 & -0.03 & 0.06 & -0.02 & 0.22 & 0.18 & 0.35 & -0.09 & -0.08 & -0.03 & -0.13 & -0.14 & 0.35 & 0.08 & 1.00 & & & & \\
\hline Political Instability & 15 & -0.02 & -0.03 & 0.04 & 0.01 & 0.03 & 0.06 & -0.07 & 0.12 & 0.01 & -0.05 & -0.16 & -0.25 & 0.04 & -0.12 & 1.00 & & & \\
\hline Democracy & 16 & 0.00 & 0.08 & -0.01 & 0.13 & 0.19 & 0.07 & 0.02 & -0.12 & -0.03 & -0.33 & -0.06 & 0.44 & 0.07 & 0.34 & -0.06 & 1.00 & & \\
\hline Ethnic Fractionalization & 17 & 0.12 & 0.13 & 0.00 & 0.02 & 0.10 & 0.06 & -0.07 & 0.24 & 0.09 & 0.08 & -0.03 & -0.33 & 0.03 & -0.09 & 0.07 & -0.23 & 1.00 & \\
\hline Religious Fractionalization & 18 & 0.14 & 0.21 & -0.04 & -0.02 & 0.18 & -0.12 & 0.03 & 0.12 & 0.07 & -0.09 & 0.15 & 0.10 & -0.20 & 0.10 & -0.05 & 0.05 & 0.38 & 1.00 \\
\hline
\end{tabular}

\section{(cc) $\mathrm{BY}$}

This work is licensed under a Creative Commons Attribution 3.0 License.

\footnotetext{
${ }^{\mathrm{i}}$ Several studies reviewed this literature over the years. Recent examples include Mildner, Lauster, and Wondi (2012), Koubi, Spilker, Tobias, and Bernauer (2014), and Murshed (2015).

ii On links from scarcity and disasters to civil war, see, e.g., Homer-Dixon (2001), Kahl (2008), and Tobias (2015), and on links to peace see, e.g., Simon (1998), Eastin (2012), and Salehyan and Hendrix (2014).

iii Le Billon (2012), Collier, Hoeffler, and Rohner (2009), and Basedau and Lay (2009) provide more discussion.

iv For cases with a positive link from scarcity and/or natural disasters to civil violence see, e.g., Homer-Dixon (2001), Kahl (2008), Reuveny (2008), Matthew \& Upreti (2010), Salehyan and Hendrix (2014), Tobias (2015), and Eastin (2015); the latter three also list case studies and actual cases where scarcity and disasters had no effect or pacified.

$\checkmark$ For examples of case studies on a link from resource abundance to civil war, see Klare (2002), Blondel (2004), Kahl (2005), and Le Billon (2012). Basedau and Lay (2009) provide examples for a link from resource abundance to lower risk of civil war.

vi The estimation sample includes country-year observations in 1975-2000 for 123 countries.

vii The NIC (2012) is not alone in these projections. For quite similar projections for civil war risk and resource tendencies to 2030 and 2045 see, respectively, the European Union Institute for Security Studies (EUISS, 2012) and the Strategic Trends Programme (STP, 2014) of the United Kingdom government.
} 